\title{
TINGKAT KEBISINGAN LALU LINTAS KENDARAAN DI GEDUNG I SEKOLAH TINGGI TEKNOLOGI INDUSTRI (STTIND) PADANG
}

\author{
Ferdian Putra ${ }^{1}$, Sri Yanti Lisha ${ }^{2}$ \\ Teknik Lingkungan, Sekolah Tinggi Teknologi Industri Padang \\ Email : ferdianputra00@gmail.com, sriyantilisha@sttind.ac.id
}

\begin{abstract}
ABSTRAK
Sekolah Tinggi Teknologi Industri Padang terletak pada lokasi yang strategis sehingga mudah diakses oleh lalu lintas kendaraan. Hal ini menguntungkan dari sisi kemudahan akses tetapi menyebabkan dampak negatif lain berupa tingkat kebisingan. Kebisingan dapat memberikan dampak kesehatan maupun psikologis pada manusia terpapar. Tujuan dari penelitian ini yaitu untuk mengetahui tingkat kebisingan di gedung I STTIND Padang yang dominan berasal dari lalu lintas kendaraan karena keberadaannya di pinggir jalan raya. Pengukuran tingkat kebisingan dilakukan pada tiga lokal/ruang kuliah yang berada di dekat akses jalan raya dengan menggunakan alat Soud Level Meter selama 7 hari kuliah (Senin sampai Sabtu). Dari hasil penelitian didapatkan yaitu tingkat kebisingan rata-rata 70,37 $\mathrm{dB}(\mathrm{A})$ dengan kebisingan rata-rata tertinggi pada Hari Sabtu yaitu 72,42 $\mathrm{dB}(\mathrm{A})$ dan tingkat kebisingan rata-rata terendah pada Hari Kamis 67,53 dB (A). Lokal tertinggi kebisingannya adalah lokal 3, yaitu 71,82 dB(A) dan terendah pada lokal 1, yaitu $68,75 \mathrm{db}(\mathrm{A})$. Hasil pengukuran tingkat kebisingan menunjukkan bahwa nilai kebisingan rata-rata berada di atas baku mutu yang di tetapkan oleh Keputusan Menteri Negara Lingkungan Hidup Nomor : KEP-48/MENLH/11/1996 tentang Baku Tingkat Kebisingan untuk kawasan sekolah atau sejenisnya adalah $55 \mathrm{db}(\mathrm{A})$. Pengaruh jenis kendaraan dengan tingkat kebisingan dapat dilihat dengan persamaan regresi $Y=41.20+0.03 \times 1+0.10 \times 2$ $0.95 \times 3$. Nilai korelasi $(\mathrm{R})$ yaitu 0,75 bermakna bahwa Hubungan antara tingkat kebisingan dengan jumlah kendaraan memiliki pengaruh yang kuat.
\end{abstract}

Kata kunci : kebisingan, lalu lintas kendaraan, lokal, baku mutu, dan Sound Level Meter.

\section{PENDAHULUAN}

Pada saat sekarang ini, berbagai aktivitas/kegiatan masyarakat baik yang disadari ataupun tidak disadari dapat menimbulkan sumber kebisingan dengan tingkat intensitas yang berbeda. Seiring dengan perkembangan zaman atau di era globalisasi teknologi dibidang industri semakin canggih dan berkembang, hal ini diakibatkan oleh karena kebutuhan masyarakat yang semakin meningkat.

Kegiatan transportasi meningkat seiring kebutuhan manusia untuk dapat berpindah tempat dalam melaksanakan aktifitasnya.
Seluruh kegiatan transportasi pasti membutuhkan bahan bakar yang akan menghasilkan emisi saat digunakan. Hal ini akan menyebabkan terjadinya pencemaran yang akan memberikan dampak negatif pada kehidupan manusia. Salah satu polutan akibat kegiatan transportasi adalah Total Suspended Particulat (TSP) serta salah satu hal yang tidak dapat dipungkiri adalah kebisingan akibat kendaraan. Di kawasan perkotaan, kendaraan bermotor merupakan sumber utama dari emisi partikulat dan menyumbang lebih dari $50 \%$ emisi partikulat di udara ambien (Srimuruganandam \& Nagendra, 2011). 
Pencemaran lingkungan akibat transportasi dapat menyebabkan dampak kesehatan dan psikologis. Dampak kesehatan cenderung muncul akibat pajanan senyawasenyawa kimia dalam jumlah besar ke tubuh manusia. Sedangkan dampak psikologis lebih diakibatkan oleh kebisingan dan getaran akibat kinerja mesin kendaraan (Marcus, 1973). Dampak kesehatan psikologis ini diterima oleh berbagai kalangan mulai dari anak-anak hingga orang dewasa, namun anak-anak akan jauh lebih menerima dampak negatif dari polusi udara dibandingkan dampak yang diterima oleh orang dewasa (Kulkarni dan Grigg, 2008).

Dalam pertimbangan pemilihan lokasi saat ini didasarkan atas pertimbangan strategis sehingga perguruan tinggi berada di dekat jalur transportasi utama kota, terutama dekat dengan lokasi jalur kereta dan mobil dengan kendaraan yang ramai. Pertimbangan lokasi strategis ini awalnya menguntungkan perguruan tinggi karena lokasi yang mudah dicapai oleh para mahasiswa. Namun seiring dengan berkembangnya kota dan meningkatnya kebutuhan transportasi menyebabkan lokasi perguruan tinggi dinilai tidak strategis dengan kenyamanan belajar di perguruan tinggi. Jarak yang dekat justru tidak menjadi pertimbangan untuk meninggalkan transportasi. Salah satu contohnya di Sydney, Australia dimana jumlah anak-anak ke sekolah dengan menggunakan kendaraan bermotor meningkat dari $22.8 \%$ di tahun 1971 menjadi 66.6\% di tahun 2003 (Ploeg et al, 2008).

Dari lokasi perguruan tinggi yang dinilai cukup strategis namun tidak cocok dengan kenyaman perkuliahan, maka timbulah permasalahan bahwa lokasi perguruan tinggi ini dekat jalan utama cenderung memiliki tingkat kebisingan yang lebih tinggi dan berujung pada dampak yang diterima oleh mahasiswa. Salah satu contoh polutan yang dapat mengganggu kenyamanan adalah kebisingan.
Sekolah Tinggi Tekonologi Industri (STTIND) Padang merupakan salah satu perguruan tinggi swasta yang ada di Padang Sumatra Barat yang berlokasi di jl. Prof DR.Hamka dekat jalan raya dan perlintasan jalur kereta api

\section{METODOLOGI}

\subsection{Waktu Dan Tempat}

Penelitian ini akan dilakukan di gedung I STTIND Padang pada ruang 1 (satu), 2 (dua) dan 3 (tiga). Waktu penelitian akan dilaksanakan pada April 2017.

\subsection{Populasi Dan Sampel}

Populasi pada penelitian ini adalah tingkat kebisingan dari lalu lintas kendaran yang melintas di gedung I STTIND Padang, sedangkan sampel pada penelitian ini adalah tingkat kebisingan di gedung I STTIND Padang.

\subsection{Variabel Penelitian}

Adapun penelitian memiliki batasan variabel penelitian supaya penelitian ini terarah yakni; jenis kendaraan yang melintas.

\subsection{Alat Pengukuran}

Alat yang digunakan pada penelitian ini meliputi : sound level meter (SLM) dan counter

\subsection{Prosedur Kerja}

Persiapan Sebelum Mengukur, pasang baterai pada tempatnya, tekan tombol power, cek garis tanda pada monitor untuk mengetahui baterai dalam keadaan baik atau tidak. Melakukan kalibrasi sebelum alat sound level meter digunakan untuk mengukur kebisingan, agar menghasilkan data yang valid.

\section{Langkah-langkah pengukuran}

Mengukur kebisingan dengan cara alat diletakkan setinggi 1,2 m dari alas lantai atau tanah pada suatu titik yang ditetapkan. 
Angka yang terlihat pada layar atau display dicatat setiap 5 detik dan pengukuran dilakukan selama 10 menit untuk setiap titik. Setelah selesai alat di matikan dengan menekan tombol "OFF".

Data hasil pengukuran dimasukkan dalam rumus Leq

$$
\mathrm{LS}=10 \log 1 / 16(\mathrm{~T} 1.1001 \mathrm{~L} 5+\ldots \ldots
$$

$+\mathrm{T} 4.1001 \mathrm{LS}) \mathrm{Db}(\mathrm{A}) \mathrm{LM}=10 \log 1 / 8$ $(\mathrm{T} 5.10$ 01L5 + ... + T7.10 01L5 ) Db (A)

$\mathrm{LSM}=10 \log 1 / 24(16.1001 \mathrm{~L} 5+\ldots+8.10$ 01L5) Db (A)

Ket :

Leq $=$ Equivalent Continuos Noise Level atau Tingkat Kebisingan Sinambung Setara ialah nilai tertentu kebisingan dari kebisingan yang berubah-ubah (fluktuatif selama waktu tertentu,. Satuannya adalah $\mathrm{db}$ (A)

$$
\begin{aligned}
& \text { LTMS = Leq selama waktu } \\
& \text { sampling tiap } 5 \text { detik } \\
& \text { LS = Leq selama siang hari } \\
& \text { LM = Leq selama malam hari } \\
& \text { LSM = Leq selama siang dan } \\
& \text { malam hari }
\end{aligned}
$$

\section{HASIL DAN PEMBAHASAN}

\subsection{Hasil Tingkat Kebisingan}

Salah satu tujuan penelitian ini adalah untuk mendapatkan hasil tingkat kebisingan lalu lintas kendaraan pada 3 (tiga) lokal yang ada di gedung I STTIND Padang, dimana pengukuran dilakukan pada hari senin-sabtu, tanggal 10-15 April 2017).

Dalam penelitian ini juga dilakukan penghitungan kendaraan bermotor selama 10 menit setiap pengukuran pada masingmasing lokal dengan mengklasifikasikan kendaran jenis kendaraan seperti di bawah ini : sepeda motor, kendaraan ringan, kendaraan berat. Untuk melihat pengaruh jumlah kendaraan terhadap tingkat kebisingan di gedung I STTIND Padang
Dari hasil pengukuran hasil tingkat

\begin{tabular}{|c|c|c|c|c|}
\hline lokasi & waktu & $\begin{array}{l}\text { hasil } \\
\text { kebisingan } \\
\mathrm{db}(\mathrm{A})\end{array}$ & $\begin{array}{l}\text { baku } \\
\text { mutu } \\
\mathrm{db}(\mathrm{A})\end{array}$ & keterangan \\
\hline \multirow{6}{*}{$\begin{array}{l}\text { gedung } \\
1 \text { lokal } 1 \\
\text { STTIND } \\
\text { Padang }\end{array}$} & senin & $\begin{array}{l}68,15 \\
d b(A)\end{array}$ & 55 & $\begin{array}{l}\text { melebihi } \\
\text { baku mutu }\end{array}$ \\
\hline & selasa & $\begin{array}{l}69,54 \\
d b(A)\end{array}$ & 55 & $\begin{array}{l}\text { melebihi } \\
\text { baku mutu }\end{array}$ \\
\hline & rabu & $\begin{array}{l}68,03 \\
d b(A)\end{array}$ & 55 & $\begin{array}{l}\text { melebihi } \\
\text { baku mutu }\end{array}$ \\
\hline & kamis & $\begin{array}{l}67,56 \\
d b(A)\end{array}$ & 55 & $\begin{array}{l}\text { melebihi } \\
\text { baku mutu }\end{array}$ \\
\hline & jum'at & $\begin{array}{l}68,20 \\
d b(A)\end{array}$ & 55 & $\begin{array}{l}\text { melebihi } \\
\text { baku mutu }\end{array}$ \\
\hline & sabtu & $\begin{array}{l}70,99 \\
\mathrm{db}(\mathrm{A})\end{array}$ & 55 & $\begin{array}{l}\text { melebihi } \\
\text { baku mutu }\end{array}$ \\
\hline
\end{tabular}
kebisingan di gedung I STTIND Padang pada tiga lokal dapat dilihat secara keseluran dalam perhari pada tabel yang ada dibawah ini :

Tabel 1. Hasil Penelitian Tingkat Kebisingan

Lokal Satu Gedung I STTIND Padang

Dapat dilhat bahwa hasil kebisingan 24 jam terendah yaitu ; pada hari kamis 67,56

\begin{tabular}{|c|c|c|c|c|}
\hline \multicolumn{5}{|c|}{ Padang } \\
\hline lokasi & waktu & $\begin{array}{l}\text { hasil } \\
\text { kebisinga } \\
\mathrm{n}\end{array}$ & $\begin{array}{l}\text { baku } \\
\text { mutu }\end{array}$ & keterangan \\
\hline \multirow{6}{*}{$\begin{array}{l}\text { gedung } \\
1 \text { lokal } 2 \\
\text { STTIN } \\
\text { D } \\
\text { Padang }\end{array}$} & senin & $\begin{array}{l}73,06 \\
\mathrm{db}(\mathrm{A})\end{array}$ & 55 & $\begin{array}{l}\text { melebihi } \\
\text { baku mutu }\end{array}$ \\
\hline & selasa & $\begin{array}{l}71,26 \\
\mathrm{db}(\mathrm{A})\end{array}$ & 55 & $\begin{array}{l}\text { melebihi } \\
\text { baku mutu }\end{array}$ \\
\hline & rabu & $\begin{array}{l}69,28 \\
\mathrm{db}(\mathrm{A}) \\
\end{array}$ & 55 & $\begin{array}{l}\text { melebihi } \\
\text { baku mutu }\end{array}$ \\
\hline & kamis & $\begin{array}{l}67,35 \\
d b(A)\end{array}$ & 55 & $\begin{array}{l}\text { melebihi } \\
\text { baku mutu }\end{array}$ \\
\hline & $\begin{array}{l}\text { jum'a } \\
\mathrm{t}\end{array}$ & $\begin{array}{l}69,85 \\
\mathrm{db}(\mathrm{A})\end{array}$ & 55 & $\begin{array}{l}\text { melebihi } \\
\text { baku mutu }\end{array}$ \\
\hline & sabtu & $\begin{array}{l}72,40 \\
\mathrm{db}(\mathrm{A})\end{array}$ & 55 & $\begin{array}{l}\text { melebihi } \\
\text { baku mutu }\end{array}$ \\
\hline
\end{tabular}
$\mathrm{db}(\mathrm{A})$, rabu 68,03 $\mathrm{db}(\mathrm{A})$, senin 68,15 $\mathrm{db}(\mathrm{A})$, jum'at $68,20 \mathrm{db}(\mathrm{A})$, selasa 69,54 $\mathrm{db}(\mathrm{A})$ dan yang tertinggi pada hari sabtu dengan hasil kebingan 34 jam 70,99 db(A).

Tabel 2. Hasil Penelitian Tingkat Kebisingan Lokal dua Gedung I STTIND 
Dapat dilhat bahwa hasil kebisingan 24 jam terendah yaitu; pada hari kamis 67,35 $\mathrm{db}(\mathrm{A})$, rabu $69,28 \mathrm{db}(\mathrm{A})$, jum'at 69,85 $\mathrm{db}(\mathrm{A})$, selasa 71,26, sabtu 72,40 dan yang tertinggi pada hari senin dengai nilai kebisingan 24 jam 73,06 db(A).

Tabel 3. Hasil Penelitian Tingkat Kebisingan Lokal Tiga Gedung I STTIND Padang

\begin{tabular}{|l|c|c|c|c|}
\hline \multicolumn{1}{|c|}{ lokasi } & waktu & $\begin{array}{c}\text { hasil } \\
\text { kebisingan }\end{array}$ & $\begin{array}{c}\text { baku } \\
\text { mutu }\end{array}$ & \begin{tabular}{c} 
keterangan \\
\hline
\end{tabular} \\
\cline { 2 - 5 } & senin & $\begin{array}{c}73,09 \\
\mathrm{db}(\mathrm{A})\end{array}$ & 55 & $\begin{array}{c}\text { melebihi } \\
\text { baku mutu }\end{array}$ \\
\cline { 2 - 5 } $\begin{array}{l}\text { Gedung } \\
\text { 1 lokal 1 }\end{array}$ & $\begin{array}{c}71,54 \\
\mathrm{db}(\mathrm{A})\end{array}$ & 55 & $\begin{array}{c}\text { melebihi } \\
\text { baku mutu }\end{array}$ \\
\cline { 2 - 5 } $\begin{array}{l}\text { STTIND } \\
\text { Padang }\end{array}$ & selasa & $\begin{array}{c}71,64 \\
\mathrm{db}(\mathrm{A})\end{array}$ & 55 & $\begin{array}{c}\text { melebihi } \\
\text { baku mutu }\end{array}$ \\
\cline { 2 - 5 } & kamis & $\begin{array}{c}67,67 \\
\mathrm{db}(\mathrm{A})\end{array}$ & 55 & $\begin{array}{c}\text { melebihi } \\
\text { baku mutu }\end{array}$ \\
\cline { 2 - 5 } & jum'at & $\begin{array}{c}73,13 \\
\mathrm{db}(\mathrm{A})\end{array}$ & 55 & $\begin{array}{c}\text { melebihi } \\
\text { baku mutu }\end{array}$ \\
\cline { 2 - 5 } & & $\begin{array}{c}73,87 \\
\mathrm{db}(\mathrm{A})\end{array}$ & 55 & $\begin{array}{c}\text { melebihi } \\
\text { baku mutu }\end{array}$ \\
\hline
\end{tabular}

Dapat dilhat bahwa hasil kebisingan 24 jam terendah yaitu; pada hari kamis 67,67 $\mathrm{db}(\mathrm{A})$, selasa 71,54 $\mathrm{db}(\mathrm{A})$, rabu 71,64 $\mathrm{db}(\mathrm{A})$, senin 73,09 , jum'at $73,13 \mathrm{db}(\mathrm{A})$ dan yang tertinggi pada hari sabtu dengan nilai 73,87 $\mathrm{db}(\mathrm{A})$

Pada saat pengukuran lokal 3 (tiga) hari senin jam 15.00 wib menit ke-9 detik ke-60 terdapat kereta api yang melintas dengan nilai leq mencapai 79,5 $\mathrm{db}(\mathrm{A})$.

Keseluruhan pengukuran menunjukkan bahwa hasil kebisingan melebihi baku mutu yang ditetapkan. Namun, berdasarkan pengamatan yang dilakukan sumber kebisingan tidak hanya berasal dari kendaraan yang melintas, namun juga berasal dari dalam lokal.

Dari ketiga lokal yang dilkakukan pengukuran kebisingan bahwa semua lokal melebihi baku mutu tetapi, lokal tiga yang nilai kebisingannya tertinggi dari pada lokal satu dan dua karena, lokal tiga pada gedung I STTIND Padang kurangnya peredam kebisingan yang berada di luar ruangan lokal
3 (tiga) sehingga sumber kebisingan dari kendaraan yang melintas kurang tereduksi.

Tabel 4. Perhitungan Gabungan Hasil Tingkat Kebisingan

\begin{tabular}{|l|l|l|l|l|}
\hline Hari & lokal 1 & lokal 2 & lokal 3 & $\begin{array}{l}\text { rata- } \\
\text { rata } \\
\text { harian }\end{array}$ \\
\hline senin & $\begin{array}{l}68.15 \\
\mathrm{db}(\mathrm{A})\end{array}$ & $\begin{array}{l}73.06 \\
\mathrm{db}(\mathrm{A})\end{array}$ & $\begin{array}{l}73.09 \\
\mathrm{db}(\mathrm{A})\end{array}$ & $\begin{array}{l}\mathbf{7 1 . 4 3} \\
\mathrm{db}(\mathrm{A})\end{array}$ \\
\hline \multirow{2}{*}{ selasa } & 70.99 & 71.26 & 71.54 & $\mathbf{7 1 . 2 6}$ \\
& $\mathrm{db}(\mathrm{A})$ & $\mathrm{db}(\mathrm{A})$ & $\mathrm{db}(\mathrm{A})$ & $\mathrm{db}(\mathrm{A})$ \\
\hline \multirow{2}{*}{ rabu } & 68.2 & 69.28 & 71.64 & $\mathbf{6 9 . 7 1}$ \\
& $\mathrm{db}(\mathrm{A})$ & $\mathrm{db}(\mathrm{A})$ & $\mathrm{db}(\mathrm{A})$ & $\mathrm{db}(\mathrm{A})$ \\
\hline \multirow{2}{*}{ kamis } & 67.56 & 67.35 & 67.67 & $\mathbf{6 7 . 5 3}$ \\
& $\mathrm{db}(\mathrm{A})$ & $\mathrm{db}(\mathrm{A})$ & $\mathrm{db}(\mathrm{A})$ & $\mathrm{db}(\mathrm{A})$ \\
\hline \multirow{2}{*}{ jumat } & 69.54 & 69.85 & 73.13 & $\mathbf{7 0 . 8 4}$ \\
& $\mathrm{db}(\mathrm{A})$ & $\mathrm{db}(\mathrm{A})$ & $\mathrm{db}(\mathrm{A})$ & $\mathrm{db}(\mathrm{A})$ \\
\hline sabtu & 68.03 & 72.4 & 73.87 & $\mathbf{7 1 . 4 3}$ \\
$\mathrm{db}(\mathrm{A})$ & $\mathrm{db}(\mathrm{A})$ & $\mathrm{db}(\mathrm{A})$ & $\mathrm{db}(\mathrm{A})$ \\
\hline rata rata & $\mathbf{6 8 . 7 5}$ & $\mathbf{7 0 . 5 3}$ & $\mathbf{7 1 . 8 2}$ & $\mathbf{7 0 . 3 7}$ \\
lokal & $\mathrm{db}(\mathrm{A})$ & $\mathrm{db}(\mathrm{A})$ & $\mathrm{db}(\mathrm{A})$ & $\mathrm{db}(\mathrm{A})$ \\
\hline
\end{tabular}

Keseluruhan pengukuran menunjukkan bahwa hasil kebisingan melebihi baku mutu yang ditetapkan. Namun, berdasarkan pengamatan yang dilakukan sumber kebisingan tidak hanya berasal dari kendaraan yang melintas, namun juga berasal dari dalam lokal.

Dari ketiga lokal yang dilkakukan pengukuran kebisingan bahwa semua lokal melebihi baku mutu tetapi, lokal tiga yang nilai kebisingannya tertinggi dari pada lokal satu dan dua karena, lokal tiga pada gedung I STTIND Padang kurangnya peredam kebisingan yang berada di luar ruangan lokal 3 (tiga) sehingga sumber kebisingan dari kendaraan yang melintas kurang tereduksi.

\subsection{Analisis Pengaruh Jenis Kendaraan dengan Tingkat Kebisingan}

Tingkat kebisingan bersumber dari lalu lintas kendaraan di gedung I STTIND Padang yang di hasilkan dari berbagai jenis 
kendaraan yaitu : sepeda motor, kendaraan ringan dan kendaraan berat. Untuk itu perlu dilakukan pengukuran terhadap kendaraan bermotor dan di analisis pengaruh jenis kendaraan bermotor tersebut dengan tingkat kebisingan. Berikut adalah output regresi dengan excel :

Tabel 5. Summary Output

\begin{tabular}{|c|c|}
\hline \multicolumn{2}{|c|}{ Regression Statistics } \\
\hline Multiple R & 0.747817006 \\
\hline R Square & 0.559230274 \\
\hline Adjusted R Square & -0.101924314 \\
\hline Standard Error & 1.178057477 \\
\hline Observations & 6 \\
\hline
\end{tabular}

Tabel 6. Koefisien Regresi

\begin{tabular}{|l|c|c|}
\hline & Coefficients & Standard Error \\
\hline Intercept & 41.20135577 & 15.93124802 \\
\hline $\begin{array}{l}\text { X Variable } \\
1\end{array}$ & 0.026144354 & 0.020955694 \\
\hline $\begin{array}{l}\text { X Variable } \\
2\end{array}$ & 0.101682857 & 0.066383153 \\
\hline $\begin{array}{l}\text { X Variable } \\
3\end{array}$ & -0.945639356 & 0.887508455 \\
\hline
\end{tabular}

Di lihat dari data di atas di dapat kan koefisien determinasi $\left(\mathrm{R}^{2}\right)$ yaitu 0,559 dan nilai korelasi ( $\mathrm{R}$ ) adalah 0,747. persamaan regresi linear nya $\mathrm{Y}=\mathrm{a}+\mathrm{b} 1 \times 1+\mathrm{b} 2 \times 2-\mathrm{b} 3 \times 3$ maka $\mathrm{Y}=41.20+0.03 \times 1+0.10 \times 2-0.95 \times 3$

Ket :

$\mathrm{Y}$ : Tingkat kebisingan

a : konstanta

$\mathrm{X}_{1} \quad$ : Sepeda motor

$\mathrm{X}_{2}$ : Kendaraan ringan

$\mathrm{X}_{3}$ : Kendaraan berat

$\mathrm{R}^{2} \quad$ : koefisien determinasi berganda

Dari persamaan regresi di atas menunjukkan konstanta variabel independent (sepeda motor, kendaraan ringan dan kendaraan berat). Bila variabel independen naik maka tingkat kebisingannya juga akan naik. ( $\mathrm{X}_{1)}$ merupakan nilai koefisien variabel sepeda motor terhadap variabel tingkat kebisingan $(\mathrm{Y})$ artinya jika jumlah sepeda motor $\left(\mathrm{X}_{1}\right)$ mengalami kenaikan maka tingkat kebisingan (Y) juga akan mengalami peningkatan sebesar 0,03 koefisien bernilai positif artinya kenaikan jumlah sepeda motor $\left(\mathrm{X}_{1}\right)$ mengakibatkan kenaikan pada tingkat kebisingan $(\mathrm{Y}) . \mathrm{X}_{2}$ merupakan koefisien variabel kendaraan ringan terhadap variabel tingkat kebisingan (Y) artinya jika jumlah kendaraan ringan $\left(\mathrm{X}_{2}\right)$ mengalami kenaikan maka tingkat kebisingan (Y) juga akan mengalami peningkatan sebesar 0,10 koefisien bernilai positif artinya kenaikan jumlah kendaraan ringan $\left(\mathrm{X}_{2}\right)$ mengakibatkan kenaikan pada tingkat kebisingan (Y). $\mathrm{X}_{3}$ merupakan koefisien variabel kendaraan berat terhadap variabel tingkat kebisingan (Y),yang mana $\mathrm{X}_{3}$ bernilai negatif, jika jumlah kendaraan berat $\left(\mathrm{X}_{3}\right)$ mengalami kenaikan maka tingkat kebisingannya (Y) akan menurun sebesar 0,95, ini di sebabkan karena jumlah kendaraan berat sedikit di bandingkan dengan jumlah sepeda motor dan kendaraan ringan.

Dari data yang di dapat bahwa nilai koefisien korelasi adalah 0,747 atau 0,75. Nilai korelasi 0,75 bermakna bahwa hubungan antara variabel $\mathrm{x}_{1}, \mathrm{x}_{2}$ dan $\mathrm{x}_{3}$ memiliki pengaruh yang kuat terhadap tingkat kebisingan, karena untuk nilai korelasi dari 0,60-0,799 masuk ke kategori tingkat hubungan yang kuat.

Dari tabel (summary output ) di dapatkan bahwa $\mathrm{R}^{2}$ adalah 0,559 mempunyai arti sebesar $56 \%$ variabel (Y) dapat di terangkan dengan variabel $(\mathrm{X})$ dan sisanya $44 \%$ di pengaruhi oleh kebisingan yang bersumber dari Kereta Api yang melintas dan kebisingan dari mahasiswa pada saat pengukuran.

\section{KESIMPULAN DAN SARAN}

\subsection{Kesimpulan}

Memperhatikan hasil keseluruhan dari penelitian maka dapat disimpulkan bahwa Dari ketiga lokal tempat pengukuran 
kebisingan nilai kebisingan tertingi pada lokal tiga dengan rata-rata kebisingan 71,82 $\mathrm{db}(\mathrm{A})$, lokal 2 (dua) 70,53 $\mathrm{db}(\mathrm{A})$ dan yang terendah pada lokal 1 yaitu $68,75 \mathrm{db}(\mathrm{A})$. Tingkat kebisingan di gedung 1 pada tiga lokal yang di lakukan pengukuran melebihi baku mutu yang telah di tetapkan oleh Keputusan Menteri Negara Lingkungan Hidup Nomor : KEP-48/MENLH/11/1996 tentang Baku Tingkat Kebisingan bahwasanya untuk kawasan sekolah atau sejenisnya adalah $55 \mathrm{db}(\mathrm{A})$ Dari persamaan regresi yang didapatkan bahwa, apabila jumlah sepeda motor dan kendaraan ringan mengalami kenaikan maka tingkat kebisingan juga akan mengalami kenaikan dan pada jenis kendaraan berat berabanding terbalik yaitu, jika jumlah kendaraan berat mengalami kenaikan maka tingkat kebisingan akan menurun, ini di sebabkan karena jumlah kendaraan berat lebih sedikit di bandingkan dengan jumlah sepeda motor dan kendaraan ringan. Nilai korelasi (R) yang di dapatkan adalah 0,75 bermakna bahwa hubungan antara variabel $\mathrm{x}_{1}, \mathrm{x}_{2}$, dan $\mathrm{x}_{3}$ memiliki pengaruh yang kuat terhadap tingkat kebisingan, karena untuk nilai korelasi dari 0,60-0,799 masuk kategori tingkat hubungan yang kuat.

\subsection{Saran}

Untuk mereduksi kebisingan pada tiga lokal tersebut perlu dilakukan penambahan barrier di gedung 1 STTIND Padang yaitu dengan Penggantian jendela, misalnya dengan kaca jendela ganda dan penambahan alumunium, fiber serta kaca

Pada ruangan bagian luar di dekat lokal 3 (tiga) perlu di lakukan penambahan barrier karena dari pengamatan yang di lihat bahwa tingkat kebisingan tertinggi terdapat pada lokal 3 (tiga). Barrier yang dapat di gunakan yaitu dengan penambahan fiber atau kaca pada bagian luar ruangan Pada saat kegiatan belajar berlangsung sebaiknya semua pintu dan jendela di tutup rapat, agar bisa mereduksi kebisingan dari luar ruangan

\section{DAFTAR PUSTAKA}

Badan Standarisasi Nasional. SNI 7231:2009 : Metode Pengukuran Kebisingan di Tempat Kerja

Departemen Kesehatan RI, Petunjuk Pelaksanaan Pengawasan Kebisingan , Jakarta : Departemen Kesehatan RI, 1995.

Departemen Pekerjaan Umum RI. (2005). Pedoman Mitigasi Dampak Kebisingan Akibat Lalu lintas Jalan. Badan Litbang Departemen Pekerjaan Umum.

Adhitya Wibawa, dkk. 2005. Penentuan Tingkat Kebisingan Lingkungan Menggunakan Alat Sound Level Meter Di Sekitar Gedung Graha Widya Wisuda.. IPB : Bandung.

Menteri Negara Lingkungan Hidup; (1996). Baku Tingkat Kebisingan, Surat Keputusan Menteri Negara Lingkungan Hidup Nomor : Kep48/MENLH/1996/25 November 1996, Jakarta.

Hidayati, N. (2007). Pengaruh arus lalu lintas terhadap kebisingan (Studi $k$ beberapa zona pendidikan di Surakarta). Dinamika Teknik Sipil.

Sasangko, D.P., Hadiyarto A. 2000. Kebisingan Lingkungan. Univ. Diponegoro. Semarang

Isran Ramli, Muhammda. 2015. Analisis Tingka Kebisingan pada kawasan perbelanjaan (Mall) d Kota Makassar dan Dampaknya terhadap Lingkungan. 
Diakses pada Tanggal 28 November 2016

Chandra, B. 2006. Pengantar Kesehatan Lingkungan. Jakarta: EGC

Doelle, L.L. 1972. Akustik Lingkungan. Jakarta:Penerbit Erlangga.

Hadi, Sutrisno. 2000. Analisis Regresi. Yogyakarta: PT Andi.

Sukarto, H. 2006. Transportasi Perkotaan dan Lingkungan. 